JOANNA NOWIŃSKA SM

Kraków

probablefdlc@gmail.com

\title{
Głos z nieba w J 12, 28 - jego percepcja i wymowa teologiczna w świetle Biblii
}

Wszechmoc Boga i możliwość działania przez każdy z elementów stworzonego świata jako prawda objawiona pozostaje niekwestionowana. Tym samym nie dziwi też fakt, że autorzy biblijni notują rozleganie się głosu z nieba. Niepisana ludowa tradycja chrześcijańska, mówiąc o Bogu, jednocześnie nakazywała podnosić palec, by wskazać niebo. Ta wiara była poddawana w wątpliwość, gdy człowiek zdobywał wiedzę o rzeczywistej budowie wszechświata. Wiedza o świecie zdawała się nie do pogodzenia z pojęciami fideistycznymi. Rodziło się zatem pytanie, czy niebo to tylko piękna biblijna przenośnia ukazująca odległość, jaka dzieli nas od Stwórcy, czy też istnieje inna rzeczywistość ${ }^{1}$, różna od ziemskiej, w której przebywa Bóg i ku której tęskni całe stworzenie (por. Rz 8, 20nn); czy naprawdę z tamtej sfery ku ziemi może przebić się głos Boga, a człowiek jest w stanie Go usłyszeć i zrozumieć.

Niebo w mentalności Hebrajczyków zawsze jest łączone z Bogiem - psalmista pisze: „Niebo jest niebem Pana, synom zaś ludzkim dał ziemię” $(\text { Ps } 115,16)^{2}$. Trudno jednoznacznie skonstatować, czy są to wyłącznie

1 W. R. F. Browing używa na określenie nieba wyrażenia „nowy wymiar” por. W. R. E. Browing, Słownik biblijny, Warszawa 2009.

${ }^{2}$ W Księgach Machabejskich nawet zastępuje imię Boga - por. Niebo, [w:] D. Fouilloux i in., Kultura biblijna. Słownik, tł. M. Żurowska, red. nauk. W. Chrostowski, Warszawa 1997. 
reperkusje mitycznej kosmologii ościennych państw, czy rezultat refleksji nad objawieniem. Zastanawia fakt, iż w grece biblijnej termin ten często występuje w liczbie mnogiej (oủpavoi), co wydaje się odzwierciedlać hebrajską liczbę podwójną שַָׁמיִ. Co ciekawe, termin grecki pozostaje z czasownikami w zdaniu w związku zgody $^{3}$, natomiast termin hebrajski traktowany jest w większości miejsc Pisma Świętego jako rzeczownik zbiorowy i łączony $\mathrm{z}$ orzeczeniem w liczbie pojedynczej. Takie różnice gramatyczne mogą wynikać z odmiennego postrzegania świata przez wspomniane środowiska kulturowe. A. Y. Collins ${ }^{4}$ wyklucza posiadanie przez starożytnych przekonania, że istnieje więcej niż jedno niebo. Księga Henocha wspomina jednak o kilku niebach (HenEt 60, 1; 71, 5), zatem w refleksji teologicznej judaizmu międzytestamentalnego pogląd na ten temat był inny. Podobnie Paweł w 1 Kor 12, 2 pisze o trzecim niebie. Analizując same terminy, można by dopatrywać się tu zastosowania zabiegu wyakcentowania przez formę gramatyczną wielkości opisywanej sfery zamieszkałej przez różne stworzenia, a ponadto mieszczącej gwiazdy, księżyc i słońce. Wszelkie cechy prawdopodobieństwa posiada również teoria o podkreślaniu w ten sposób aspektu tajemnicy przez zaznaczanie swoistego cienia czy też istnienia życia przez ukazanie szerokiej płaszczyzny jego rozwoju. Całkiem możliwe także w przypadku hebrajskiego

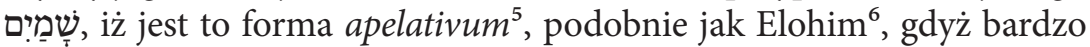
często nazywane jest ono miejscem przebywania $\mathrm{Boga}^{7}$.

${ }^{3}$ Zgodność podmiotu i orzeczenia co do liczby i rodzaju - por. Gramatyka opisowa języka polskiego zćwiczeniami, pod red. W. Doroszewskiego i B. Wieczorkiewicza, t. 2, Warszawa 1961, s. 202.

${ }^{4}$ A. Y. Collins, Niebo, [w:] Encyklopedia biblijna, red. P. A. Achtemeier, Warszawa 1999.

${ }^{5}$ Nazwa całego rodzaju desygnatów - por. Apelatiwum, [w:] E. Sobol, Słownik wyrazów obcych, Warszawa 2000.

${ }^{6}$ Por. S. Szymik, Imiona 'El oraz 'Elohîm jako określenia Boga w Biblii Hebrajskiej, [w:] Mów, Panie, bo sługa Twój stucha. Księga pamiątkowa dla Księdza Profesora Ryszarda Rubinkiewicza SDB w 60. rocznice urodzin, zebr. i oprac. W. Chrostowski, Warszawa 1999, s. 206-218, zwł. s. 218.

${ }^{7}$ R. L. Harris, L. Archer, B. K. Waltke, The Theological Wordbook of the Old Testament,

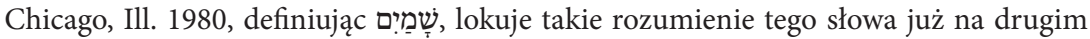


Niebo według relacji biblijnej wyszło z ręki Boga (por. Ps 102, 26). On określany jest mianem jego Stwórcy (por. Rdz 1, 1; 14, 19; Iz 45, 18), a także władcy (nadaje mu nazwę - por. $\operatorname{Rdz} 1,8$; Ps 78, 23), a zatem pomimo iż w Pwt 4, 2 (a także m.in. w Jdt 7, 28; 1 Mch 2, 37) jest wzywane na świadka, nie posiada charakteru bóstwa („Bo wszyscy bogowie pogan to ułuda, a Pan uczynił niebiosa" - 1 Krn 16, 26). Znane są jego bogactwa (rosa, deszcz, śnieg - por. Pwt 33, 13), stanowi mieszkanie wojsk niebieskich (por. Iz 45, 12), które to podobnie jak chmury podlegają rozkazom Jahwe (por. Iz 48, 13; Iz 24, 12), samo jednak cieszy się ograniczoną, czyli niewieczną egzystencją (por. Iz 51, 6a). Według natchnionego autora księgi Hioba głębiny Boga przewyższają niebo (Hi 11, 7n), co podtrzymuje Ha 3, 3, podając, że majestat Boga „okrywa (przykrywa) niebiosa”. Już wcześniej zresztą Kronikarz notuje w modlitwie Salomona: „niebo

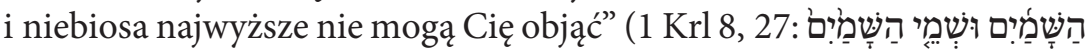

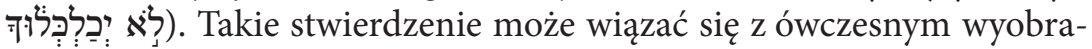
żeniem nieba jako piętrowego pałacu, w którym mieszka Bóg będący Królem - per analogiam wobec władców ziemskich.

Psalmista ukazuje niebo m.in. jako tron Boga (por. Ps 11, 4; 103, 19), w czym pozostaje zgodny z tradycją mądrościową (por. Mdr 9, 10; 18, 15) i prorocką (Iz 66, 1). Zatem gdy wybuchnie gniew Boga, niebo i ziemia „wstrząśnie się w posadach” (Iz 13, 13). Oczywiście wszystkie wspomniane treści zasadzają się na kosmologii znanej autorom biblijnym, tym samym ewoluują w obrębie świętego tekstu wraz z rozwojem świadomości ich ludzkich autorów. Wydaje się jednak, iż zagłębianie się w te zagadnienia z punktu widzenia ówczesnej nauki nie jest potrzebne w ramach niniejszego artykułu.

Bóg ukazany w Biblii jest Tym, który działa, tak przejawia się Jego istnienie $^{8}$. Jedną z form Jego żywej obecności stanowi słowo wypowiadane na różne sposoby, czemu też poświęcono odpowiednio dużo miejsca w badaniach egzegetycznych. Pismo Święte jednak mówi nie tylko o tym, co stanowi efekt przekazu, ale również o głosie Boga.

miejscu, po kategoriach fizykalnych.

${ }^{8}$ Por. M. Uglorz, Jahwe - Bóg Izraela. Zarys starotestamentowej teologii Boga, Warszawa 2002, s. 45. 


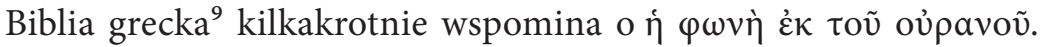
Bezpośrednio jako głos Boga definiuje go Pwt 4, 36 w jednym z kulminacyjnych passusów w kontekście teologicznej refleksji nad historią narodu wybranego włożonej w usta Mojżesza. Greckie $\pi$ aı $\delta \varepsilon \tilde{v} \sigma a$, którym tłumacz LXX przełożył hebrajskie ?ִיְֵֵַ, określa tu cel tego objawienia: wychowanie, zdyscyplinowanie, pouczenie ${ }^{10}$. Zatem głos Boga, aby dokonać tego, co zostało zamierzone, musiał być zrozumiały dla odbiorców. Zaznacza się tu wyjątkowość Boga, który chce się komunikować z ludźmi i wielkość wybrania Narodu, który ma takiego Boga ${ }^{11}$. W Pwt 4, 36 następuje wyraźne rozgraniczenie pomiędzy przekazem $\mathrm{z}$ nieba a tym, który ma miejsce na ziemi. Ten ostatni posiada aspekt wizualny i on opisany jest jako pierwszy:

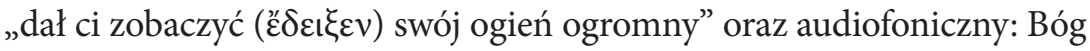
pozwolił słyszeć Jego słowa ( się więc, iż niebo nie jest jedynym medium głosu Boga. Deuteronomista ukazuje tutaj Boga w całej specyfice swojej teologii wraz z aurą tajemnicy, do której się często odwołuje, a może chwilami także grozy (głos z ognia), jakich nie brakuje w jego dziele. Warto zaznaczyć, iż w przekonaniu tego autora cała rzeczywistość leży w mocy Boga Jedynego Jahwe ${ }^{12}$ (nie zajmuje się tym, czy istnieją inni bogowie i w jakim stopniu decydują o losach świata - według Deuteronomisty nie mają oni żadnej władzy) - stąd może On komunikować się z ludźmi w sposób, jaki pragnie ${ }^{13}$. Czy w poruszanym passusie szczególnie zaznacza się motyw uduchowienia wydarzenia, tak charakterystyczny dla deuteronomistycznej wizji historii ${ }^{14}$ - można

${ }^{9}$ Temat dotyczy tekstu greckiego, stąd bazą do odniesień starotestamentalnych pozostanie LXX.

${ }^{10}$ Por. יָסָר:, [w:] Whitaker's Revised BDB Hebrew-English Lexicon, [w:] BibleWorks 6;

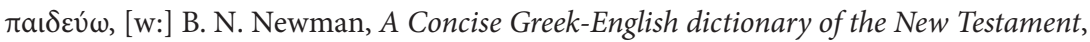
Stuttgart 1993.

${ }^{11}$ Por. J. Blenkinsopp, Księga Powtórzonego Prawa, [w:] B. N. Newman, A Concise Greek - English Concise Dictionary of the New Testament, dz. cyt., s. 157.

${ }^{12}$ Por. T. Brzegowy, Pięcioksiag Mojżesza, Tarnów 2002, s. 220; J. Blenkinsopp, Ksiegga Powtórzonego Prawa, dz. cyt., s. 157.

${ }^{13}$ Por. T. Brzegowy, Pięcioksiag Mojżesza, dz. cyt., s. 220.

${ }^{14}$ Por. tamże, s. 222. 
dyskutować. Głos z nieba stanowi raczej wyraz wierności Boga danym wcześniej Izraelowi obietnicom ${ }^{15}$.

Powstaje pytanie, na czym polega starotestamentalna specyfika

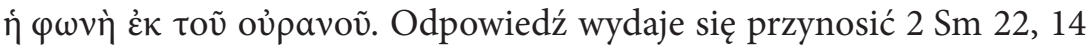
i jego dublet Ps $18,14^{16}$. Tłumaczenie LXX przekazuje w obu tych wer-

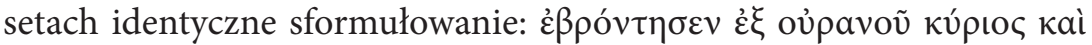

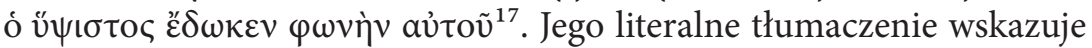
na zaistnienie najpierw grzmotu $\mathrm{z}$ nieba - potem dopiero pada enigmatyczne stwierdzenie „Najwyższy dał swój głos”. Ponieważ jednak wersety te stanowią zamkniętą całość, a konstrukcja semantyczna ww. 7b-16 nie wskazuje na stopniowanie treści, można zgodnie z prawidłami retoryki hebrajskiej mówić tu o paralelizmie synonimicznym. עִלְיוֹן to Ten, który przewyższa niebiosa, jest ponad światem i innymi bogami ${ }^{18}$, podlegają Mu też siły kosmosu. Analizowane wersety w obu tekstach umieszczone są w passusach opisujących Jahwe jako Wojownika, który walczy w obronie Dawida (Por. 2 Sm 22, 7; Ps 18, 7), nic więc dziwnego, że Jego głos posiada charakter gromu - warto się zastanowić, czy nie ma on pełnić funkcji okrzyku wojennego. Kontekst 1 Sm 22 jest zresztą batalistyczny. Henryk Witczyk dopatruje się w tym obrazie wyakcentowania aspektu bliskości Jahwe ${ }^{19}$, co jest jak najbardziej zasadne w kontekście Jego woli zbawczej. O mocy głosu z nieba świadczy, iż morze, symbol wszelkich wrogich Bogu potęg, ucieka (odsłania się dno - 2 Sm 22, 15-16). W. 16 podkreśla dodatkowo aurę grozy i sprzeciw Jahwe jako koloryt wspomnianej metaforyki.

${ }^{15}$ Por. tamże, s. 220.

${ }^{16}$ A. F. Campbell, J. W. Flanagan, Pierwsza i Druga Księga Samuela, [w:] Katolicki komentarz biblijny, red. nauk. wyd. oryg. R. E. Brown, J. A. Fitzmyer, R. E. Murphy, red. nauk. wyd. pol. W. Chrostowski, Warszawa 2001, s. 263; por. A. Tronina, Bóg przybywa z Synaju. Staroizraelskie formuly teofanijne a początki religii Izraela, Lublin 1989, s. 76-88.

17 Tekst hebrajski 2 Sm 22, 14 i Ps 18, 14 różni się zakończeniem: Ps 18 posiada jesz-

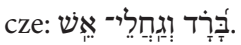

${ }^{18}$ H. Witczyk, Teofania w Psalmach, Kraków 1985, s. 162n.

${ }^{19}$ H. Witczyk, „Pokorny wołał i Pan go wysłuchat” (Ps 34,7a). Model komunikacji diafonicznej w Psalmach, Lublin 1997, s. 78. 
Tekstem biblijnym, w którym pojawia się motyw głosu z nieba, jest również Syr 46, 17. Znajduje się on w obrębie tzw. Pochwały Ojców (Syr 44-49), co ciekawe w passusie, który je opisuje nie, jak można by oczekiwać, dzieje Mojżesza czy Jozuego, lecz Samuela. Następujący w kolejnych wersetach opis świętej wojny ${ }^{20}$ i poprzedzająca wzmianka o natarciu wrogów Izraela

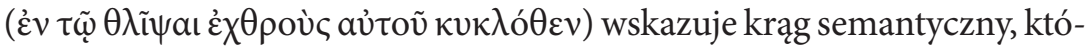
remu podporządkowuje się interpretacja analizowanego wyrażenia. Bóg

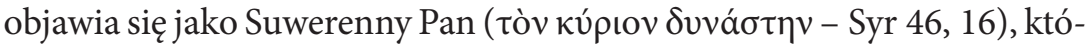
ry wezwany na pomoc, podejmuje obronę ludu. Paralelizm trzech współrzędnych członów tworzących zdanie złożone ww. 17n:

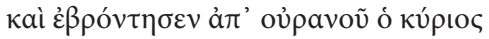

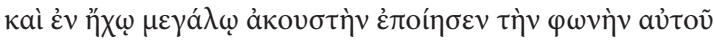

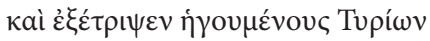

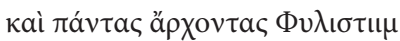

czyni głos Boga narzędziem walki, którym pokonuje On nieprzyjaciół. Obraz grzmotu ma najprawdopodobniej na celu ekspozycję Jego mocy oraz wyakcentowanie przerażenia, jakie wzbudza Jahwe wśród wrogów. Warto zwrócić uwagę na greckie określenie ñXoc. Suponuje ono, iż słyszany dźwięk odbiegał w swoim charakterze od mowy ludzkiej ${ }^{21}$, posiadał jednak brzmienie uchwytne dla ucha. Nie można więc mówić w tym przypadku o słowach, jakkolwiek według powyższych analiz zaistniał przekaz pozawerbalny. Istnieje różnica między przyimkami zastosowanymi z greckim oủpavóc odpowiednio w 2 Sm 22, 14 i Syr 46, 17 - غ̇k obecne w pierwszym z tych tekstów wskazuje bardziej na wychodzenie głosu z wnętrza nieba, a ảđó tylko na kierunek od, z nieba.

O potędze głosu z nieba mówi Jr 51, 16 - w przekazie LXX Jr 28, 16:

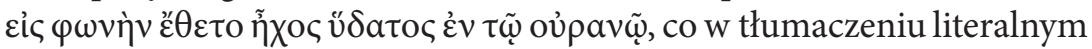
brzmi: „w głosie [domyślnie: Jego] umiejscowiony jest dźwięk [hałas]

${ }^{20}$ Więcej na temat świętej wojny patrz G. von Rad, Holy War in Ancient Israel, Michigan 1991.

${ }^{21} \tilde{\eta} \chi \chi \circ$, , [w:] J. P. Louw, E. A. Nida, Greek-English Lexicon of the New Testament Based on Semantic Domains, New York 1988. 
wód w niebie”, a może bardziej „odgłos wód w niebie” brzmiący potężnie. Zaznacza się tu pogląd starożytnych stwierdzający istnienie wód podziemnych i nadziemnych (por. np. Rdz 1). Kontekst wskazuje na zabieg wyakcentowania wszechmocy i wszechwładzy Boga, ponad którą nikt nie jest w stanie się wznieść. I znów posiada tu ona charakter zbawczy - Jahwe wyzwala Izraelitów, tym razem z Babilonu.

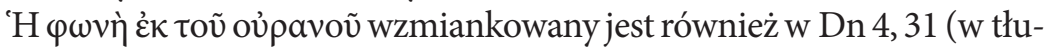
maczeniu Biblii Tysiąclecia jest to w. 28). Pada w odpowiedzi na pychę Nabuchodonozora zawartą w słowach: „Czy nie jest to wielki Babilon, który ja zbudowałem jako siedzibę królewską siłą mojej potęgi i chwałą mojego majestatu?" (Dn 4, 27). Tym razem głos z nieba nie tylko jest sły-

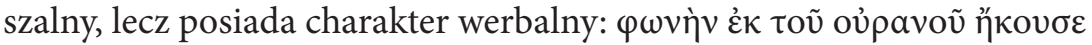
бoì $\lambda \varepsilon ́ \gamma \varepsilon \tau \alpha$. Wypowiedziane słowa to wyrok na króla (notabene wypełnienie snu) oznajmiający, iż królestwo zostanie mu odebrane. Głos tu wręcz spada na króla (נְפַ) i jak wskazuje analiza porównawcza z Iz 9, 7, jest to głos Boga. Cały przekaz posiada formę wyroczni, co - jak wskazuje J. J. Collins jest specyfiką apokalips historycznych ${ }^{22}$.

Podobnie wyraźny przekaz dokonany za pośrednictwem głosu z nieba ma miejsce w opisie chrztu Jezusa u synoptyków. O pewnej zagadkowości tego wydarzenia świadczy zapis Marka i Łukasza, którzy używają formy

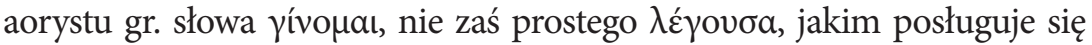
Mateusz. Termin zastosowany przez drugiego i trzeciego ewangelistę kładzie akcent na zaistnienie, wejście w życie ${ }^{23}$, czyli zarazem też dokonanie się, spełnienie już teraz słów, jakie zostają wypowiedziane („Tyś jest mój Syn umiłowany, w Tobie mam upodobanie” - Mk 1, 11; por. paralelne Mt 3, 17; $Ł \mathrm{k} 3,22)$. Natomiast $\lambda \dot{\varepsilon} \gamma o v \sigma \alpha$ pozostawia wyrażenie jedynie na poziomie mowy - prawdopodobne jest, iż miało służyć wyakcentowaniu osoby przekazującej $^{24}$. Lapidarny Markowy opis chrztu Jezusa i następujące po nim

${ }^{22}$ Za: M. Parchem, Księga Daniela. Wstęp, przekład z oryginału, komentarz, Częstochowa 2008, s. 322.

${ }^{23}$ yívoual, [w:] J. P. Louw, E. A. Nida, Greek-English Lexicon of the New Testament Based on Semantic Domains, dz. cyt.

${ }^{24}$ Taka interpretacja wydaje się jak najbardziej właściwa, gdyż domniemanymi adresatami pierwszej Ewangelii mieli być Żydzi znający Boga jako Tego, który komunikuje się 
wyrzucenie Chrystusa na pustynię lokuje wydarzenie głosu z nieba w ciekawym kontekście. Skompilowane teksty Ml 3, 1; Wj 23, 20 i Iz 40, $3^{25}$ przywołują w Mk 1, 2b-3 oczekiwanie Izraela na interwencję Boga, jaka miała zaistnieć w osobie Mesjasza. Postać Jana Chrzciciela jest służebna wobec Jezusa, również w konstrukcji tekstu pełni rolę wprowadzającą, antycypującą. Pierwsze zdanie, którego podmiotem staje się Chrystus, to stwierdzenie: „W owym czasie przyszedł Jezus z Nazaretu w Galilei i przyjął od Jana chrzest w Jordanie" (Mk 1, 9). Od tego momentu zmienia się perspektywa. Jezusowe zanurzenie w wodach Jordanu to wyraz gotowości i w konsekwencji też zgoda na podjęcie misji zbawczej. Od razu więc jakby pada też odpowiedź z nieba. Składa się ona w relacji synoptyków z trzech elementów, którymi są: otwarte niebo, zstępujący Duch i rozlegający się głos. Jedynie Łukasz umieszcza dodatkowo motyw modlitwy Jezusa (Łk 3,21), co sugeruje, iż powyższe kwestie posiadają charakter odpowiedzi danej przez Ojca. Otwarte niebo suponuje możliwość dostępu do Boga ${ }^{26}$, Jego planu zbawienia ${ }^{27}$. Ewangelista nie stosuje tu ávoí $\gamma \omega$ typowego w opisach sytuacji otwierania ${ }^{28}$, lecz mocniejsze semantycznie $\sigma \chi \chi_{i} \zeta \omega$, termin oznaczający rozrywanie, rozłączanie, pękanie ${ }^{29}$. Sugeruje tym samym gwałtowność czynności, moc spoczywającą u jej początku, tę, która zaraz zstępuje w postaci Ducha. I tu zaznacza się różnica w spojrzeniu poszczególnych synoptyków: Łukaszi Mateusz, opisując zstąpienie Ducha na Jezusa, stosują દ̇ंí, tym samym zaznaczając niejako miejsce ${ }^{30}$,

z człowiekiem, a zarazem teocentryczni w postrzeganiu rzeczywistości.

${ }^{25}$ S. Haręzga, Jezus i Jego uczniowie. Model chrześcijańskiej formacji w Ewangelii według św. Marka, Lublin 2006, s. 38.

${ }^{26}$ S. Haręzga, Jezus i Jego uczniowie. Model chrześcijańskiej formacji w Ewangelii według św. Marka, dz. cyt., s. 43; por. M. Bednarz, Jezus Sługa Pańskim według Nowego Testamentu, Tarnów 2001, s. 159-160.

${ }^{27}$ J. Nowińska, Ap 12 jako teologia historii, „Ruch Biblijny i Liturgiczny” 62 (2009) nr 4, s. 269-283.

${ }^{28}$ ảvoí $\gamma \omega$, [w:] R. Popowski, Wielki słownik grecko-polski Nowego Testamentu, Warszawa 1997.

${ }^{29} \sigma \chi \underline{\zeta} \zeta \omega$, [w:] R. Popowski, Wielki słownik grecko-polski Nowego Testamentu, dz. cyt.

${ }^{30} \varepsilon \dot{\pi} \mathrm{i}$, [w: ] T. Friberg, Analytical Lexicon to the Greek New Testament, Grand Rapids, MI 1994. 
akcentując wybór osoby, jej szczególną tożsamość, natomiast Marek poprzez użycie عí wskazuje na to, co się dokonuje we wnętrzu Syna Bożego - Duch zstępuje do głębi, w Jezusa ${ }^{31}$. Enigmatyczną pozostaje kwestia stopnia partycypacji czy świadomości zdarzenia osób uczestniczących w nim. Mk 1, 10 i Mt 3, 16 wspominają, iż Jezus ujrzał rozwierające się niebo i Ducha jak gołębicę zstępującego na siebie $(\varepsilon \tilde{\delta} \delta \varepsilon v)^{32}$. Grecki czasownik ópáw nie precyzuje, jakie widzenie ma tu miejsce - czy jest to zjawisko optyczne, czy wewnętrzne. Jedynie czwarty ewangelista, który w opisie chrztu Jezusa nie przekazuje głosu z nieba, ukazuje Jana Chrzciciela jako tego, który widział rozwierające się niebo (J 1,32). Gołębicę jako postać cielesną wzmiankuje tylko Łk - on też nie określa, kto i co mógł zobaczyć; taka relacja może być uwarunkowana inną kondycją tego ewangelisty, który według wszelkich badań historycznych nie mógł być naocznym świadkiem opisywanych wydarzeń. Pozostaje otwartym pytanie, czy głos z nieba w czasie chrztu Jezusa był tylko Jego wewnętrznym doświadczeniem mającym umocnić Go przed czasem pustyni, czy i w jakim stopniu był percepowany przez zgromadzonych wówczas nad Jordanem. Warto w tym momencie, poszukując argumentacji, przywołać słowa zapisane przez wszystkich synoptyków jako rozlegające się właśnie z nieba. W swoim trzonie leksykalnym pozostają niemal identycz-

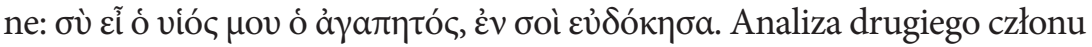
tego zdania, gdzie zostało zastosowane $\varepsilon \hat{\delta} \delta$ oké $\omega \mathrm{w}$ formie indicativus aoristi 1 os. 1. poj. pozwala na konstatację, iż tekst ten miał w zamierzeniu charakter świadectwa dla otaczających Jezusa ${ }^{33}$. Jedynie oni potrzebowali takiej informacji. Dodatkowo fakt, iż cała sytuacja rozgrywa się nad Jordanem, suponuje jej status eksplikacyjny. Warto zauważyć, iż w mentalności judaizmu

${ }^{31}$ Elৎ, [w:] T. Friberg, Analytical Lexicon to the Greek New Testament, dz. cyt.

${ }^{32}$ Nie ma wzmianki o doznaniach słuchowych, paralelnych do widzianego obra$\mathrm{zu}$ - por. A. Malina, Pedagogia i tajemnica głosu Boga (Mk 1, 11; 9, 7), „Verbum Vitae” 7 (2005), s. 93-118, zwł. s. 99.

${ }^{33}$ Forma aorystu wskazuje na upodobanie Boga w Jezusie wcześniejsze od chrztu - por. R. Bartnicki, Chrzest Jezusa w Jordanie w perspektywie historiozbawczej (Mk 1, 9-11; Mt 3, 13-17; Lk 3, 21-22; J 1, 29-34), [w:] R. Bogacz, W. Chrostowski, Verbum caro fatum est. Księga pamiątkowa dla Ks. Prof. Tomasza Jelonka $w 70$ rocznicę urodzin, Warszawa 2007, s. 99-109, zwł. s. 106. 
prawda musiała być oparta o wypowiedzi przynajmniej dwóch świadków - tutaj jednym jest Bóg Ojciec, drugim Jan Chrzciciel. Wydaje się, iż cennym byłoby pójść dalej w interpretacji słów przekazanych przez głos z nieba i zwrócić uwagę na sformułowanie ó ả $\gamma a \pi \eta \tau$ tó, nota bene znane już w Starym Testamencie jako określenie Izraela w relacji do Boga (por. Jr 38, 20). W tym kontekście słowa głosu z nieba nie stanowiłyby zaskoczenia dla świadków opisywanego wydarzenia, gdyby nie fakt, iż Jezusa nie dotyczy wyznanie grzechów, a Jan reaguje zdziwieniem na Jego wolę przyjęcia chrztu posiadającego charakter pokutny (por. Mt 3, 14n). Stanisław Haręzga ${ }^{34}$ odwołuje się tu do LXX i wskazuje, że termin ten stosowano w translacji hebrajskiego יחידיד, jak to ma miejsce np. w Rdz 22, 2. 12.16 w odniesieniu do Izaaka. Na podstawie tak dalece idących analiz porównawczych wymienionych tekstów egzegeta wysnuwa wniosek o paschalnym akcencie głosu $\mathrm{z}$ nieba ${ }^{35}$. Tezę tę wydaje się potwierdzać umieszczenie chrztu Jezusa przed Jego pobytem na pustyni, gdzie urzeczywistnia się już wojna ze złem, która swoją kulminację znajdzie w wydarzeniach męki, a puentę w fakcie zmartwychwstania.

Specyficzna jest synoptyczna relacja Przemienienia Jezusa. Wyrażenie

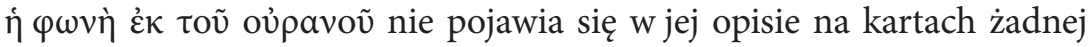
ewangelii, jedynie w paralelnym 2 P 1, 18: „I słyszeliśmy, jak ten głos do-

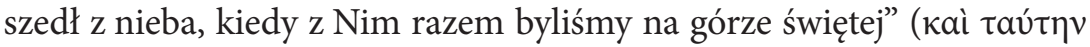

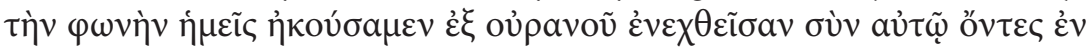

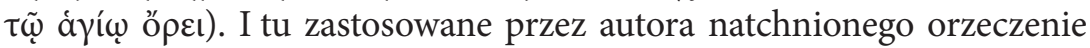

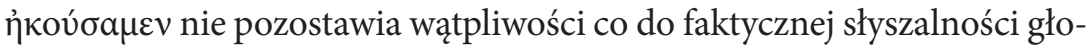
su z nieba, gdyż nie jest możliwe, aby w przypadku wewnętrznego przeżycia było ono identyczne w odbiorze trzech osób. Apostołowie rejestrują tu konkretne słowa. Warto skonstatować, iż wyraźnie określają one Osobę wypowiadającą je: „To jest mój Syn umiłowany, w którym mam upodobanie" (2 P 1, 17) ma prawo zagościć tylko w ustach Ojca. Kontekst wskazuje cel pojawienia się głosu z nieba - jest nim objawienie trzem uczniom chwały Jezusa. O nadprzyrodzoności całej sytuacji oraz jej zaskakującym dla

${ }^{34}$ S. Haręzga, Jezus i Jego uczniowie..., dz. cyt., s. 43-44. Temat ten podejmuje też R. Bartnicki, Chrzest Jezusa w Jordanie w perspektywie historiozbawczej (Mk 1, 9-11; Mt 3, 13-17; Lk 3, 21-22; J 1, 29-34), art. cyt., s. 106.

${ }^{35}$ S. Haręzga, Jezus i Jego uczniowie..., dz. cyt., s. 44. 
odbiorców kształcie świadczy fakt, iż autor 2 Listu św. Piotra w zdaniach następnych usiłuje zwrócić uwagę adresatów listu na pisma prorockie i ich wypełnienie w Jezusie, tak jakby chciał skupić ich na namacalnej rzeczywistości Chrystusa, nie zaś cudowności wydarzeń z Jego ziemskiej egzystencji (por. 2 P 1, 19). Wydaje się istotnym również skomentowanie tego tekstu w świetle synoptycznych opisów przemienienia Jezusa. Dokonuje się ono jako swoista przeciwwaga wobec zapowiedzi męki. Potwierdzenie relacji miłości między Ojcem a Synem stanowi centrum tych perykop ${ }^{36}$ i ma za zadanie ułatwić uczniom przyjęcie krzyżowej śmierci Jezusa nie jako przekleństwa ze strony Boga, ale jako elementu Jego planu zbawienia człowieka, co ostatecznie stanie się dla nich zrozumiałe w poranek wielkanocny ${ }^{37}$. Potwierdza to nakaz milczenia, jaki nadaje im Chrystus, zaraz gdy opuszczają miejsce przemienienia. Trwa debata akademicka nad precyzyjnym określeniem starotestamentalnych odniesień słów, jakie przypisywane są głosowi z nieba ${ }^{38}$. Większość autorów pozostaje zgodnych co do łączenia ich z Pieśniami o cierpiącym Słudze Pańskim (Iz 42 i in).

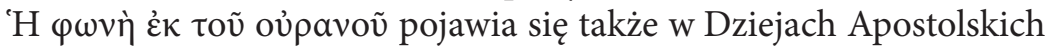
(Dz 11,9). Tutaj nie budzi zdumienia ani trwogi, zostaje jednoznacznie opisane jako głos Jezusa i pełni funkcję eksplikacyjną w kontekście wątpliwości Piotra odnośnie do spożywania pokarmów rytualnie nieczystych. Całość posiada charakter wizji, ale nie teofanii. Analizowane sformułowanie wydaje się tu posiadać charakter jedynie synonimiczny

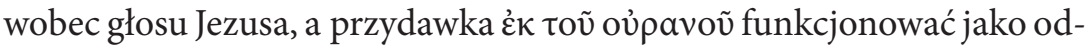
nośnik do transcendencji i akcent wymiaru popaschalnego całej sytuacji.

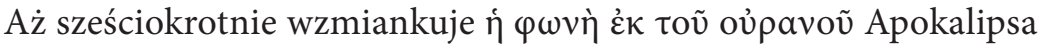
św. Jana. Z wyjątkiem Ap 14, 2 posiada on wymiar werbalny, a słowa, które padają, posiadają formę imperatywu (Ap 10, 4. 8; 11, 12; 14, 13; $18,4)$. Wydawane dyspozycje wskazują na autorytet i władzę osoby bę-

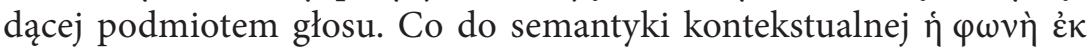

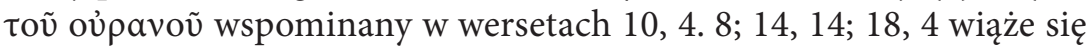

\footnotetext{
${ }^{36}$ M. Bednarz, Jezus Stuga Pańskim według Nowego Testamentu, dz. cyt., s. 183.

${ }^{37}$ Por. A. Paciorek, Ewangelia według świętego Mateusza. Wstęp, przekład z oryginału, komentarz, rozdziały 14-28, Częstochowa 2008, s. 179.

${ }^{38}$ M. Bednarz, Jezus Sługa Pańskim według Nowego Testamentu, dz. cyt., s. 184.
} 
z wojną dobra ze złem (jednym z centralnych, jeśli nie najważniejszym motywem Apokalipsy ${ }^{39}$ ) i ma na celu ocalenie członków armii Baranka. W Ap 10, 4 nie jest on zidentyfikowany, wydaje rozkaz w sposób autorytarny, kontroluje objawienie lub doświadczenie, jakie jest udziałem skryby, co suponuje, iż jest to głos władcy, posiadający powagę większą niż wcześniejszy przekaz anioła czy gromów. Przy powtórnej dyspozycji przezeń wydanej pełne posłuszeństwo piszącego wskazuje na wielki autorytet głosu i jego kierowniczą rolę wobec zdarzeń. Co ciekawe, istnieje dogłębne porozumienie między głosem a audytorem, padające słowa okazują się zrozumiałe dla piszącego, a on odpowiada stosownie do poleceń.

Nieco więcej informacji na temat głosu z nieba podaje Ap 11, 12 - wezwanie skierowane do Dwóch Świadków przynaglające do przejścia w niebo i ich wejście ukazuje niebo jako sferę obecności głosu, nie lokuje go tylko w wymiarze wrażenia słuchowego. Celem tego imperatywu jest ukazanie przynależności Dwóch Świadków, a tym samym też tryumfu, gdyż znajdują się w miejscu całkowicie niedostępnym dla wrogów, ci ostatni widzą ich, lecz nie są w stanie dosięgnąć. Wstępowanie w obłoku suponuje Bożą ingerencję.

W Ap 14, 2-3a autor natchniony konstatuje:

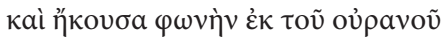

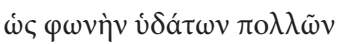

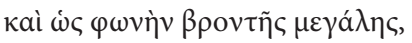

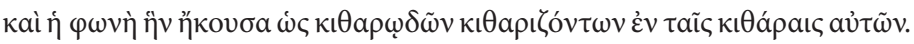

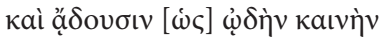

Nie zostaje tu opisany wymiar werbalny głosu z nieba - poza stwierdzeniem wykonywania pieśni. Kontekst wskazuje na armię Baranka jako

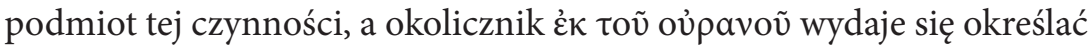
miejsce, z którego skryba obserwuje całą sytuację, jako znajdujące się poniżej, gdyż sam dźwięk według poprzedzającego wersetu dochodzi z góry

${ }^{39}$ Więcej zob. J. Nowińska, Motyw wojny dobra ze złem w Apokalipsie św. Jana, Warszawa 2006. 
Syjon. Odbiorca - jak domniemuje D. A. Aune ${ }^{40}$ - w pierwszej chwili nie jest w stanie rozróżnić poszczególnych fonemów, stąd nasuwają mu się skojarzenia $\mathrm{z}$ adekwatnymi tonami natury jak intensywny szum wody czy grzmot. Po chwili dźwięki te zaczynają w uchu audytora nabierać podobieństwa do wydawanych przez harfę, by następnie odważył się on na zabieg doszukiwania się w nich jakiegoś konkretnego, posiadającego sens i układ melodyczny utworu. Cały czas jednak autor natchniony stosuje przysłówek $\omega \varsigma$, zaznaczając, iż jego spostrzeżenia nie dookreślają w pełni charakteru głosu z nieba. R. Wall, porównując ten passus z pa-

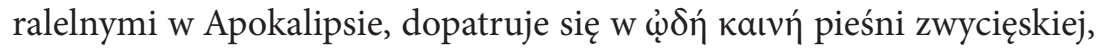
pełnej radości z wyzwolenia ${ }^{41}$.

Głos z nieba słyszalny w Ap 14, 13 ogłasza trzecie i ostatnie przed definitywnym rozstrzygnięciem wezwanie do nawrócenia. Posiada ono formę błogosławieństwa dla tych, którzy okazali się wierni aż do śmierci. Podobny cel posiada orędzie głosu z nieba w Ap 18, 4 - to wezwanie do ucieczki od zła o zabarwieniu osobistym, na co wskazuje określenie

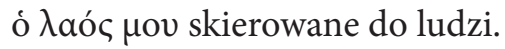

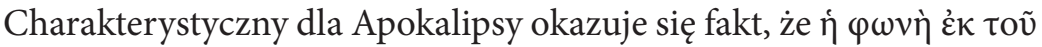
oủpavoũ nie budzi zdziwienia, a cel jego pojawienia się jest zrozumiały dla odbiorcy. Polecenie zapisania tego, co mówi głos, wskazuje na ponadczasową ważność jego orędzia, tym samym też suponuje wielki autorytet mówiącego. W żadnym miejscu autor nie próbuje identyfikować głosu z Bogiem, niemniej treść padających imperatywów oraz ich kontekst pozwala na taką konstatację.

Powyższe analizy nakreślają pewne semantyczne tło dla badań głosu z nieba i jego percepcji w J 12, 28nn. Warto zwrócić uwagę, iż wspomniane teksty biblijne akcentują przede wszystkim bliskość Boga, Jego wolę zbawczą oraz podporządkowaną jej moc jako czynnik nadrzędny. Nowy Testament wprowadza tu pewne novum: istnienie bliskiej relacji między Ojcem a Jezusem, której zasadniczy koloryt stanowi miłość. Celem głosu z nieba staje się świadectwo wobec odbiorców, a nawet więcej: perswazja,

${ }^{40}$ D. A. Aune, Revelation, t. 2, Dallas 1997, s. 808.

${ }^{41}$ Więcej zob. J. Nowińska, Motyw wojny dobra ze złem w Apokalipsie św. Jana, dz. cyt., s. $242 \mathrm{nn}$. 


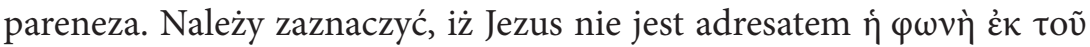
oủ pavoũ. Wydaje się istotnym wyakcentowanie w tym miejscu, że żaden ze wspomnianych wyżej autorów biblijnych nie zajmuje się stopniem zrozumienia głosu z nieba, ani nie opisuje różnorodności jego percepcji wśród odbiorców. Jan zatem nie posiada bezpośrednich pierwowzorów czy odniesień. Chociaż grzmot pojawia się jako swoisty obraz głosu Boga, to w żadnym passusie nie pada stwierdzenie interwencji czy mowy Anioła. Czwarty Ewangelista posiada własną optykę.

Tytułowy tekst niniejszego artykułu wydaje się być jakby syntezą pas-

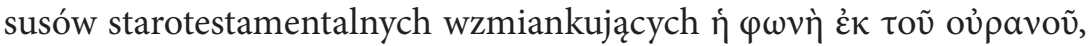
gdyż zawiera nie tylko cytat $z$ werbalnym przesłaniem, lecz jednocześnie, paradoksalnie, podaje różnorodność jego odbioru przez obecnych: „Tłum stojący to usłyszał i mówił: «Zagrzmiało!» Inni mówili: «Anioł przemówił do Niego»" (J 12, 29). W konstrukcji Czwartej Ewangelii przynależy on do perykopy J 12, 20-36. Co do wyodrębnienia ww. 20-36 rozdziału 12 jako pewnej całości zgodna jest większość egzegetów ${ }^{42}$. Wyakcentowują w niej jednakże różne treści. Analiza semantyczna słownictwa wydaje się potwierdzać tytuł nadany temu passusowi przez R. E. Browna ${ }^{43}$ - brzmi on: „sceny przygotowujące paschę i śmierć - nadejście godziny”. Stanisław Mędala zwraca uwagę, iż jest to ostatni dialog Jezusa ze światem ${ }^{44}$. Swoista klamra, którą tworzą: pytanie Greków o Jezusa (w. 21) i Jego odejście od Żydów w miejsce ukryte (w. 36b), ukazuje obecność motywu wiary pogan $^{45}$, a niewiary Izraela, wydaje się on jednak drugoplanowy w stosunku do analizowanego tematu. O specyfice kontekstu, w którym

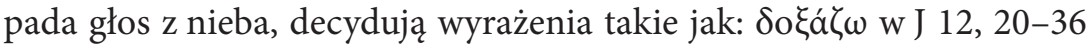
użyte trzykrotnie w formie czasownikowej (w Nowym Testamencie też

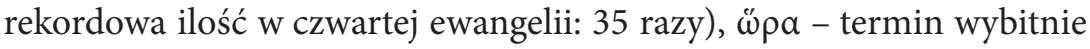
Janowy (pojawia się w całej ewangelii J 26 razy, w tym fragmencie 3 razy),

${ }^{42}$ Por. L. Stachowiak, Ewangelia według św. Jana, Poznań 1975, s. 287; J. H. Neyrey, The Gospel of John, Cambridge 2007, s. 218.

${ }^{43}$ R. E. Brown, The Gospel According to John, New York 1966, t. 1, s. 465.

${ }^{44}$ S. Mędala, Chrystologia ewangelii św. Jana, Kraków 1993, s. 309.

${ }^{45}$ Za postrzeganiem Greków jako reprezentantów świata pogańskiego w tym tekście opowiada się m. in. L. Stachowiak, Ewangelia według św. Jana, dz. cyt., s. 288. 
$\pi \alpha \tau$ $\rho$ - podobnie tutaj 3 razy (51 razy w czwartej ewangelii), viò àv$\theta \rho \omega ́ \pi$ ov - również trzykrotnie (u autora Janowego zawsze w odniesieniu do wywyższenia, bliskości wobec Boga, innej kondycji niż ludzie - potwierdzenie w tekstach).

\section{Strukturę J 12, 20-36 można przedstawić następująco:}

${ }^{20}$ A wśród tych, którzy przybyli, aby oddać pokłon Bogu w czasie święta, byli też niektórzy Grecy. ${ }^{21}$ Oni więc przystąpili do Filipa, pochodzącego z Betsaidy Galilejskiej, i prosili go mówiąc: «Panie, chcemy ujrzeć Jezusa». ${ }^{22}$ Filip poszedł i powiedział Andrzejowi. Z kolei Andrzej i Filip poszli i powiedzieli Jezusowi.

${ }^{23}$ A Jezus dał im taką odpowiedź «Nadeszła godzina, aby został uwielbiony Syn Człowieczy.

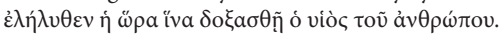

${ }^{24}$ Zaprawdę, zaprawdę, powiadam wam

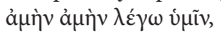

Jeżeli ziarno pszenicy wpadłszy w ziemię nie obumrze,

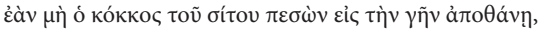
ale jeżeli obumrze,

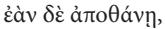

${ }^{25}$ Ten, kto kocha swoje życie,

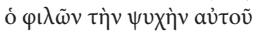

a kto nienawidzi swego życia na tym świecie,

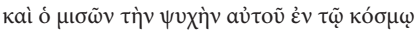

${ }^{26}$ A kto by chciał Mi służyć,

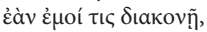
a gdzie Ja jestem,

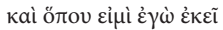
A jeśli ktoś Mi służy,

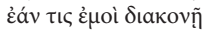

${ }^{27}$ Teraz dusza moja doznała lęku

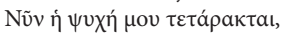

Nie, właśnie dlatego przyszedłem na tę godzinę

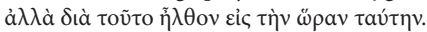

Wtem rozległ się głos z nieba:

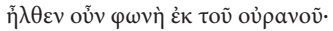

${ }^{29}$ Tłum stojący to usłyszał i mówił:

zostanie tylko samo

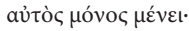
obfity plon przynosi

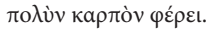
traci je,

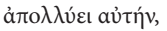
zachowa je na życie wieczne.

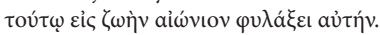
niech idzie za Mną

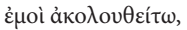
tam będzie i mój sługa.

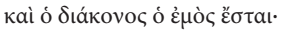
uczci go Ojciec.

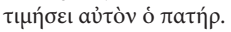
i cóż mam powiedzieć? Ojcze, wybaw Mnie od tej godziny.

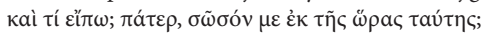
${ }^{28}$ Ojcze, wsław Twoje imię!».

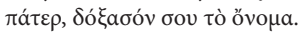
"Już wsławiłem i jeszcze wsławię".

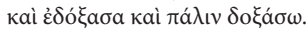

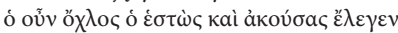

«Zagrzmiało!»

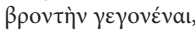

Inni mówili: «Anioł przemówił do Niego».

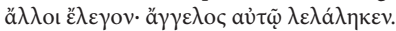

${ }^{30} \mathrm{Na}$ to rzekł Jezus: «Głos ten rozległ się nie ze względu na Mnie, ale ze względu na was.

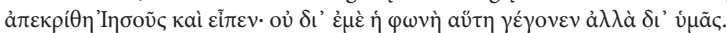

${ }^{31}$ Teraz odbywa się sąd nad tym światem.

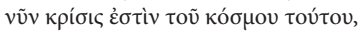

Teraz władca tego świata zostanie precz wyrzucony.

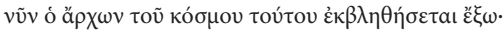

${ }^{32}$ A Ja, gdy zostanę nad ziemię wywyższony, przyciągnę wszystkich do siebie».

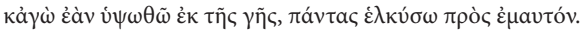

${ }^{33}$ To powiedział zaznaczając, jaką śmiercią miał umrzeć.

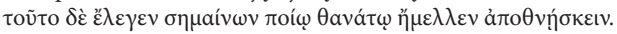

${ }^{34} \mathrm{Na}$ to tłum $\mathrm{Mu}$ odpowiedział:

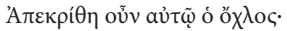


«Myśmy się dowiedzieli z Prawa, że Mesjasz ma trwać na wieki.

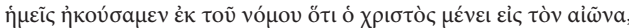

Jakżeż Ty możesz mówić, że potrzeba wywyższyć Syna Człowieczego?

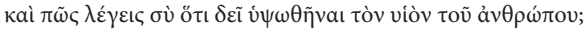

Któż to jest ten Syn Człowieczy?»

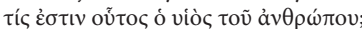

${ }^{35}$ Odpowiedział im więc Jezus: «Jeszcze przez krótki czas przebywa wśród was światłość.

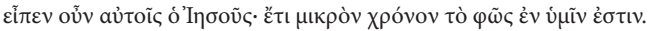

Chodźcie, dopóki macie światłość,

$\pi \varepsilon \rho$

A kto chodzi w ciemności, nie wie, dokąd idzie.

aby was ciemność nie ogarnęła.

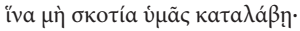

${ }^{36}$ Dopóki światłość macie, wierzcie w światłość, abyście byli synami światłości». To powiedział Jezus i odszedł, i ukrył się przed nimi.

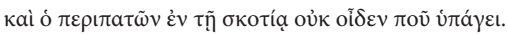

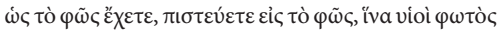

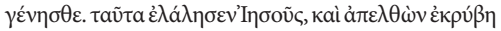
ảं' $\alpha u ̛ \tau \tilde{\omega} v$.

Schemat ten ukazuje kilka jednostek literackich wewnątrz tekstu okalającego J 12, 28nn. Motyw Greków przybyłych na Paschę i ich pragnienie poznania Jezusa sprawia wrażenie narracyjnego podprowadzenia pod teologiczną konstatację Jezusa o nadejściu godziny. Warto zaznaczyć, iż Janowe określenie $̋$ pa jest technicznym synonimem męki i śmierci Chrystusa $^{46}$. Ku niej zorientowane jest całe Jego życie ziemskie, i co ważne - nie jest to tutaj, jak u synoptyków, godzina panowania ciemności (por. Łk 22, 53), lecz uwielbienia Jezusa ${ }^{47}$. Ono, a nie cierpienie, stanowi szczyt posłannictwa Syna Bożego. Forma perfectum $\varepsilon \lambda \eta \lambda \varepsilon \theta \varepsilon v$ wskazuje, iż czas, który się teraz rozpoczyna, był już zaplanowany i faktycznie trwał, obecnie zostają objawione skutki tego, co on ze sobą przynosi. Od w. 23 rozpoczynają się w analizowanym passusie tematy antycypujące mękę. Chiastyczna konstrukcja dotycząca obumierania i owocowania ziarna (w. 24) w zestawieniu $\mathrm{z}$ analogicznym układem słownym dotyczącym życia (w. 25) poprzedza kolejny chiazm na temat służby (w. 26ab) i obecności Jezusa. Podsumowanie tego ostatniego zawarte w zdaniu: çáv

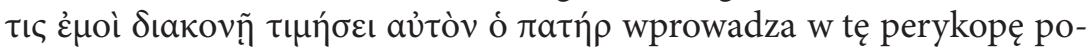
stać Ojca i antycypuje opis relacji Boga i Jezusa obecny w w. 27. Termin

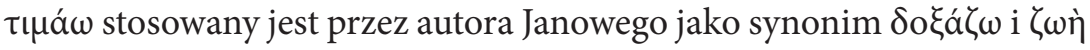

${ }^{46}$ Por. R. E. Brown, The Gospel According to John, dz. cyt., t. 1, s. 470.

${ }^{47}$ Por. I. de la Potterie, Męka Jezusa Chrystusa według Ewangelii Jana, Kraków 2006, s. 16 n. 
aíẃvıov ${ }^{48}$, a według M. C. de Boer'a ${ }^{49}$ stanowi prostszy stylistycznie jego wariant, spójny ze słowami ảyatá $\omega, \varphi \iota \lambda \hat{\varepsilon} \omega$. R. E. Brown ${ }^{50}$ wprost widzi w w. 25 zaproszenie do wejścia i partycypowania w relacji miłości istniejącej między Ojcem a Jezusem.

Tytułowy fragment stanowi centrum J 12, 20-36 na płaszczyźnie konstrukcji literackiej. Zmaganie Jezusa z lękiem (w. 27-28a) ukazane w formie paralelizmu antytetycznego znajduje puentę $\mathrm{w}$ relacji głosu $\mathrm{z}$ nieba, którego percepcja, jakże zróżnicowana (w. 29-30), zostaje poddana komentarzowi Jezusa. On następnie dokonuje interpretacji całego wydarzenia w formie paralelizmu klimaktycznego na bazie tematu swojej śmierci (ww. 31-33), do czego wraca jeszcze w w. 35-36a po pytaniu o tożsamość Syna Człowieczego. Jeśli by spojrzeć na J 12, 20-36 przez pryzmat semantyki, to można rozpoznać tu strukturę koncentryczną utworzoną przez konkretne motywy:

- Pragnienie poznania Jezusa

- Śmierć Jezusa - wymiar utraty i zysku

- Lęk Jezusa i różne możliwości poradzenia sobie z nim

- Odniesienie do Ojca

- Ingerencja Ojca i różny jej odbiór przez poszczególnych świadków

- Śmierć Jezusa - wymiar osądu i miłości do człowieka

- Zachęta do troski o posiadanie synostwa, Jezus ukrywa się

Warto zauważyć, iż powyższe analizy uzupełniają się i pozostają zgodne co do centralnej roli J 12,28n. Na pierwszy plan natomiast wydają się wysuwać dwa motywy śmierci Jezusa i Jego relacji z Ojcem, które niby w lustrze zyskują swój rezonans w człowieku rozumianym jako jednostka i jako rodzaj ludzki.

Głos z nieba poprzedzony zostaje Jezusowymi słowami o lęku. Grecki termin $\tau \alpha \rho a ́ \sigma \sigma \omega$ pojawia się sześciokrotnie w Ewangelii według św. Jana: raz w formie aktywnej, a w pozostałych fragmentach w passivum;

\footnotetext{
${ }^{48}$ Por. R. E. Brown, The Gospel According to John, dz. cyt., t. 1, s. 475.

${ }^{49}$ M. C. de Boer, Johannine Perspectives on the Heath of Jesus, Kampen 1996, s. 192n.

${ }^{50}$ Por. R. E. Brown, The Gospel According to John, dz. cyt., t. 1, s. 475.
} 
trzykrotnie za jego pomocą autor natchniony przekazuje przeżycia Jezusa. W J 12, 28nn wielu egzegetów ${ }^{51}$ dopatruje się reminiscencji doświadczeń z Ogrodu Oliwnego opisanych przez synoptyków. Można by postawić pytanie o to, czego dotyczy lęk Jezusa w perykopie Janowej. Poprzedzające analizowany passus wersety wskazują na utratę życia. Chiazm o ziarnie i warunkach owocności egzystencji człowieka na wieczność uzasadnia niezbędność obumierania, ale tylko wówczas, gdy posiada ono wymiar daru i przejścia do nowej rzeczywistości (owoc, życie wieczne), a nie wyłącznie unicestwienia. O tym, jak trudne jest to doświadczenie, mówi lęk Jezusa przed ową godziną. C. H. Dodd ${ }^{52}$ zwraca uwagę, iż autor Janowy pomija tutaj wewnętrzną walkę Jezusa, której wyraz dają synoptycy w opisie modlitwy w Getsemani. Czwarty ewangelista przekształca też fakt ostatecznej akceptacji woli Ojca przez Jezusa w jawną, otwartą, niemal natychmiastową deklarację. Dochodzi tu do głosu cel, jaki stawia sobie autor Janowy: wyakcentowanie Bóstwa Chrystusa ${ }^{53}$, a także miłość Syna do Ojca, której istotę stanowi bezwarunkowe zaufanie i zryw gotowości ${ }^{54}$ mającej przed oczyma perspektywę powierzenia się Temu, kto kocha. C. H. Dodd ${ }^{55}$ proponuje zestawienie modlitwy Jezusa zawartej w Łk 22, 42 z J 12, 27n, które okazuje się prowadzić do ciekawych wniosków:

Łk 22, 42

Ojcze, jeśli chcesz, zabierz ode Mnie ten kielich!

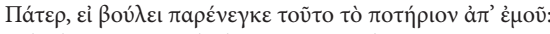
Jednak nie moja wola, lecz Twoja niech się stanie!

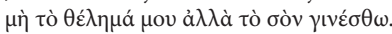

J 12, 27a. 28a

Ojcze, wybaw Mnie od tej godziny

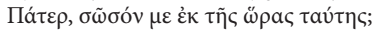

Ojcze, wsław Twoje imię!

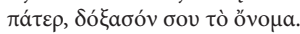

${ }^{51}$ Por. C. H. Dodd, Historical Tradition in the Fourth Gospel, Cambridge 1963, s. 69; C. K. Barett, The Gospel According to St. John. An Introduction with Commentary and Notes on the Greek Text, Philadelphia 1978, t. 1, s. 421.

${ }^{52}$ C. H. Dodd, Historical Tradition..., dz. cyt., s. 68.

${ }^{53}$ Cel czwartej Ewangelii podaje sam autor w J 20, 31: „Te zaś [znaki] zapisano, abyście wierzyli, że Jezus jest Mesjaszem, Synem Bożym, i abyście wierząc mieli życie w imię Jego”.

${ }^{54}$ W. H. Cadman, The Open Heaven. The Revelation of God in the Johannine Sayings of Jesus, New York 1969, s. 161.

${ }^{55}$ C. H. Dodd, Historical Tradition..., dz. cyt., s. 69. 
Adekwatność semantyczna obu tych wersetów pozwala skonfronto-

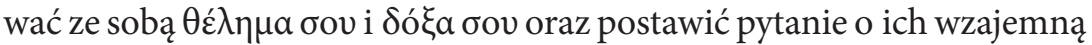
relację. Sam tekst czwartej Ewangelii nie zamieszcza tych terminów obok siebie, chociaż łączy przekazywane przez nie treści. Tak jest np. w J 17, 4: "Ja Ciebie otoczyłem chwałą na ziemi przez to, że wypełniłem dzieło,

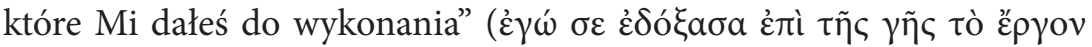

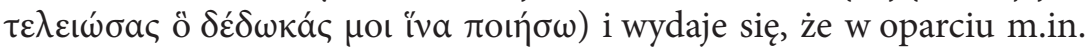
o ten fragment można postawić tezę o synonimiczności sformułowań

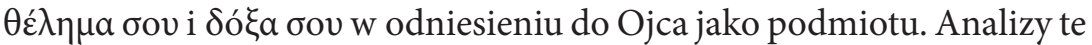
sugerowałyby motyw posłuszeństwa Jezusa jako wiodący w J 12, 28nn ${ }^{56}$, ale wzmianka o chwale Boga wydaje się przesuwać akcent na inną płaszczyznę. Konfrontacja tytułowego fragmentu z J 17, 24: „Ojcze, chcę, aby także ci, których Mi dałeś, byli ze Mną tam, gdzie Ja jestem, aby widzieli chwałę moją, którą Mi dałeś, bo umiłowałeś Mnie przed założeniem

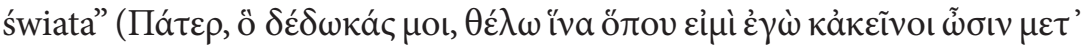

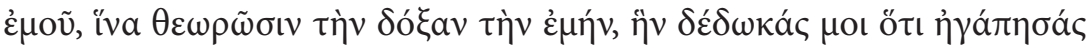

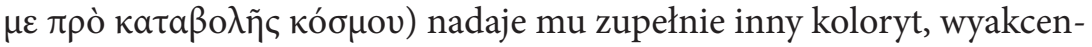
towując miłość Ojca do Syna. Argumentem potwierdzającym takie stanowisko jest fakt, że podstawowym określeniem Jezusa poza Jego imieniem w czwartej Ewangelii jest właśnie termin „Syn" ${ }^{77}$, a główny zarzut stawiany Jezusowi według czwartego Ewangelisty brzmi: „,nie tylko nie zachowywał szabatu, ale nadto Boga nazywał swoim Ojcem, czyniąc się równym Bogu" $(J 5,18)$. Tak zarysowana relacja dopełniona zostaje

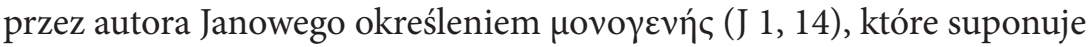
szczególny wymiar miłości wobec Jednorodzonego oraz prawdą o obec-

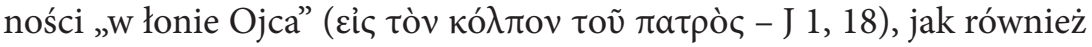
współdziałaniu $(J 5,19)$, równej czci $(J 5,23)$, a przede wszystkim poja-

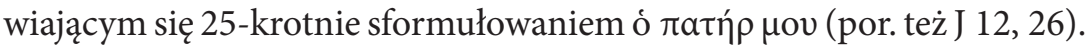
Bezpośrednio o miłości, która łączy Go z Ojcem, mówi Jezus w J 3, 35:

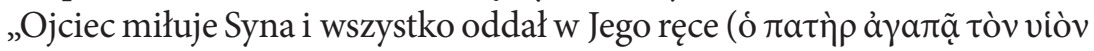

${ }^{56}$ Por. tamże, s. 70; por. też W. H. Cadman, The Open Heaven..., dz. cyt., s. 161; por. C. K. Barett, The Gospel According to St. John, dz. cyt., s. 421.

${ }^{57}$ Por. F. Moloney, Teologia świętego Jana, [w:] Katolicki komentarz biblijny, dz. cyt., s. 2191 . 


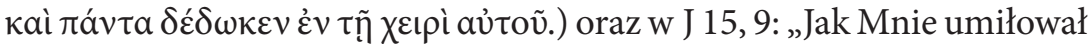

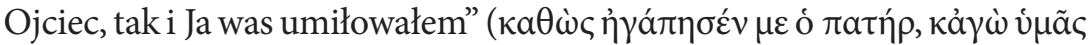

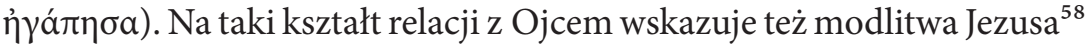
z J 12, 27n - w lęku każdy szuka oparcia tylko u osób, których miłości jest pewny, doświadcza ich bliskości i posiada pełne zaufanie. Tekst: „Teraz dusza moja doznała lęku i cóż mam powiedzieć? Ojcze, wybaw Mnie od tej godziny. Nie, właśnie dlatego przyszedłem na tę godzinę. Ojcze, wsław Twoje imię!" (J 12, 27n) jest wyrazem faktycznego zmagania lub możliwości zmagania, którego zaistnienie w takiej sytuacji byłoby bardzo prawdopodobne, niemniej konkluzja akcentuje głęboką świadomość

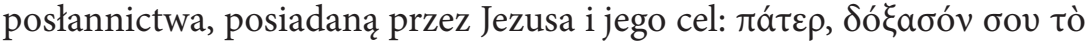
övoua. W kontekście powyższych analiz prośba ta stanowi jakby wołanie o pełne objawienie miłości Boga ludziom. Na związek semantyczny

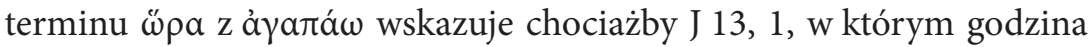
wspominana przez Jezusa zostaje dookreślona jako i் $\omega \rho \alpha$ iv $\alpha \mu \varepsilon \tau \alpha \beta \tilde{n}$

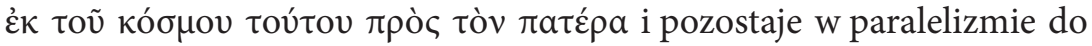

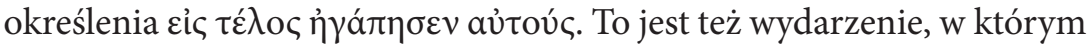
ukazuje się cała głębia relacji między Nim a Ojcem - potwierdza to sam Chrystus w słowach: „Oto nadchodzi godzina, a nawet już nadeszła, że się rozproszycie - każdy w swoją stronę, a Mnie zostawicie samego. Ale Ja nie jestem sam, bo Ojciec jest ze Mną" (J 16, 32). Werset ten jest koherentny wobec J 12, 27. L. Morris dostrzega tu flesz na krzyż Jezusa, co jest jak najbardziej kompatybilne z powyższymi treściami dzięki także w. 32 („A Ja, gdy zostanę nad ziemię wywyższony, przyciągnę wszystkich do

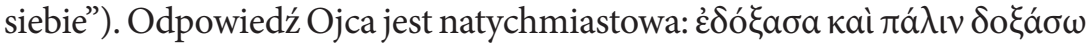

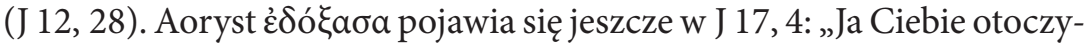
łem chwałą na ziemi przez to, że wypełniłem dzieło, które Mi dałeś do

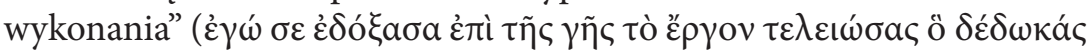
$\mu$ o îva $\pi$ oıń $\sigma \omega)$, co pozwala na konstatację, iż dotyczy on wcielenia i życia Jezusa ${ }^{59}$. Natomiast futurum $\delta$ o $\xi a ́ \sigma \omega$ wydaje się być w tym kontekście

${ }^{58}$ Por. C. A. Evans, The Voice from Heaven: A Note on John 12 : 28, „Catholic Biblical Quarterly” 43 (1981) nr 3, s. 407.

${ }^{59}$ Por. R. E. Brown, The Gospel According to John, dz. cyt., t. 1, s. 476n. 
zapowiedzią Paschy (por. J 12, 6) ${ }^{60}$. W. H. Cadman ${ }^{61}$ dostrzega tu zwiastun ukazania człowiekowi, na czym polega chwała Boga, co następnie przez wywyższenie Jezusa zaowocuje wprowadzeniem ludzi w tę jedność, w której pozostaje Ojciec z Synem ${ }^{62}$.

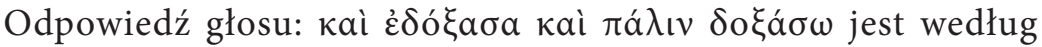
R. A. Whitacre ${ }^{63}$ bardzo znaczącym, doniosłym stwierdzeniem relacji, jaka zachodzi między Ojcem a Synem, której ludzie nie rozumieją. Świadkowie wydarzenia odbierają je zupełnie inaczej niż Jezus: „Tłum stojący to usłyszał i mówił: «Zagrzmiało!» Inni mówili: «Anioł przemówił do Niego»" (J 12, 29). Warto zaznaczyć, iż ta teofania dostępna jest dla wszystkich ${ }^{64}$ i ma miejsce ze względu właśnie na tłum (w. 30: „Na to rzekł Jezus: «Głos ten rozległ się nie ze względu na Mnie, ale ze względu na was»"). Czy zatem ponosi fiasko co do przekazu treści? Tak różna od Jezusowej percepcja głosu z nieba nie powinna budzić zdziwienia, gdyż w J 5, 20 Jezus w swoisty sposób przewiduje taką reakcję tłumu na Jego relację z Ojcem, gdyż mówi: „Ojciec bowiem miłuje Syna i ukazuje Mu to wszystko, co On sam czyni, i jeszcze większe dzieła ukaże $\mathrm{Mu}$, aby-

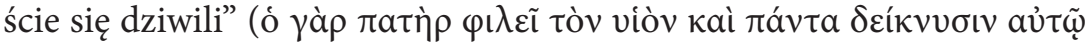

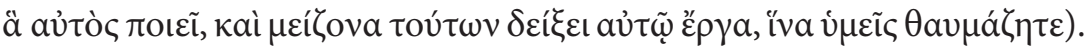

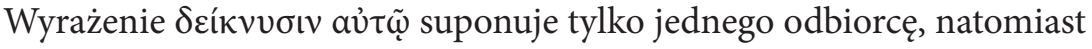
zdumienie staje się udziałem wszystkich świadków wydarzenia. Jezus zna Ojca o wiele lepiej niż ktokolwiek z ludzi - w J 5, 36n mówi przecież: „Ja mam świadectwo większe od Janowego. Są to dzieła, które Ojciec dał Mi do wykonania; dzieła, które czynię, świadczą o Mnie, że Ojciec Mnie posłał. Ojciec, który Mnie posłał, On dał o Mnie świadectwo. Nigdy nie słyszeliście ani Jego głosu, ani nie widzieliście Jego oblicza; nie macie także słowa Jego, trwającego w was, bo wyście nie uwierzyli w Tego, którego On posłał”. Jezus słyszy i rozumie, gdyż posiada z Ojcem synowski

\footnotetext{
${ }^{60}$ Por. P. H. Lightfoot, St. John's. A Commentary, London 1966, s. 241.

${ }^{61}$ W. H. Cadman, The Open Heaven..., dz. cyt., s. 161.

${ }^{62}$ Por. też św. Tomasz z Akwinu, Komentarz do ewangelii Jana, Kęty 2002, s. 777.

${ }^{63}$ R. A. Whitacre, Joannine Polemic. The Role of Tradition and Theology, Chico 1982, s. 91.

${ }^{64}$ L. Morris, The Gospel According to John. The English Text with Introduction, Exposition and Notes, Grand Rapids, Mich. 1971, s. 597.
} 
kontakt (por. J 10, 30: „Ja i Ojciec jedno jesteśmy”). Zewnętrzni świadkowie tego wydarzenia słyszą dźwięki, lecz różnie je odbierają. J. H. Neyrey ${ }^{65}$ prezentuje opinię, że to właśnie tak zróżnicowany stopień posiadania umiejętności słuchania stanowi istotę tego fragmentu. Część audytorium odnosi wrażenie, że rozlega się grzmot, inni podejrzewają - jak sugeruje J. Lierman ${ }^{66}$ - iż jest to coś więcej - głos anioła. Ten ostatni sugeruje - jak trafnie zauważa św. Tomasz z Akwinu ${ }^{67}$ w swoim komentarzu do czwartej Ewangelii - że audytorium postrzega Jezusa wyłącznie jako człowieka - stąd niemożliwe jest, by Bóg kontaktował się z Nim bezpośrednio, najwyżej poprzez wysłańca, którego pomocy Chrystus miałby w ich opinii potrzebować. Z pewnością wszelkie padające w tekście konstatacje uwarunkowane są kształtem relacji z Bogiem, którą posiadają odbiorcy, często zdominowanej przez wiele schematów ${ }^{68}$ - problem ten

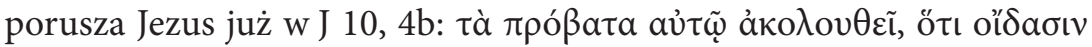



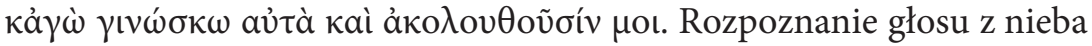
jako grzmotu wydaje się być kliszą ludzkiego lęku, chociaż analiza na tle Starego Testamentu pozwalałaby raczej oczekiwać stwierdzenia zwia-

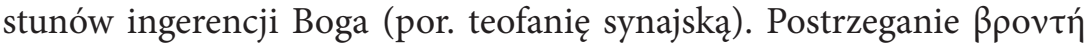
jako głosu Jahwe jest charakterystyczne nie tylko dla deuteronomisty, lecz również dla psalmisty i sięga aż do stosowanego przez Biblię słownika, w którym pip posiada dwupoziomową semantykę głosu i grzmo$\mathrm{tu}^{69}$. Odwołując się do takiej argumentacji F. J. Moloney ${ }^{70}$ stwierdza, iż błąd tłumu zasadzał się na fakcie rozpoznania hałasu jako swego rodzaju mediacji raczej niż obecności. W stwierdzeniu „Anioł przemówił do Niego" daje też znać o sobie ludzkie poszukiwanie nadprzyrodzoności,

${ }^{65}$ J. H. Neyrey, The Gospel of John, dz. cyt., s. 219.

${ }^{66} \mathrm{G}$. Burge, Revelation and Discipleship in St. John's Gospel, [w:] Challenging Perspectives on the Gospel of John, ed. by J. Lierman, Tübingen 2006, s. 235-251, zwł. s. 239.

${ }^{67}$ Św. Tomasz z Akwinu, Komentarz do ewangelii Jana, dz. cyt., s. 777.

${ }^{68}$ Por. L. Morris, The Gospel According to John, dz. cyt., s. 597.

${ }^{69}$ Więcej patrz: H. Witczyk, „Pokorny wołał i Pan go wystuchał” (Ps 34,7a). Model komunikacji diafonicznej w Psalmach, Lublin 1997, s. 74nn.

${ }^{70}$ F. J. Moloney, The Gospel of John, Collegeville 1998, t. 4, s. 360. 
nadzwyczajności. Tu tymczasem wyraża się miłość Ojca do Syna, która niejako przymusza Ojca do potwierdzenia najbliższej z możliwych - Synowskiej przynależności Jezusa ${ }^{71}$.

Prezentowane niezrozumienie jest w pewnym sensie również konsekwencją zamknięcia odbiorców na wcześniejsze nauczanie Jezusa, co stanowi nadbudowę na uprzedniej alienacji wobec Boga objawiającego się w Pismach ${ }^{72}$. Dopiero życie Jezusa jako Syna Człowieczego odczytane w perspektywie paschalnej pozwoli ludziom nauczyć się powoli prawdy o miłości Ojca i ośmieli do wejścia w taką relację z Nim tych, którzy dotąd całą nadzieje pokładali w Prawie, w legalizmie uczynków, a nie po-

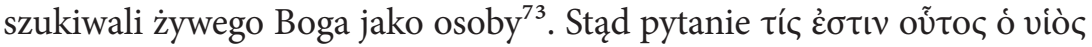

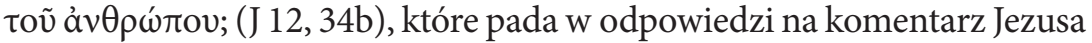
wyjaśniający głos z nieba. Jezus przez świadków wydarzenia z J 12 nie jest jeszcze postrzegany jako Ten, który stanowi pomost między Bogiem a ludźmi, Syn Boży, a jednocześnie Syn Człowieczy. Stwierdzenie zawarte w w. 34a: „ «Myśmy się dowiedzieli z Prawa, że Mesjasz ma trwać na wieki” w odpowiedzi na słowa Jezusa o Jego śmierci suponuje, iż tłum rozpoznaje w Nim Mesjasza, jednak pozostaje tylko w kręgu własnego wyobrażenia tej postaci oraz własnej interpretacji dopiero co mającego miejsce wjazdu Jezusa do Jerozolimy ${ }^{74}$ (jest to jak najbardziej zgodne z przytaczaną wyżej interpretacją Tomasza z Akwinu co do rozpoznania głosu z nieba jako pochodzącego od anioła). Stąd odrzucenie zapowiedzi pasji Jezusa oraz kontrowersja dotycząca określenia Syn Człowieczy (w. 34b). Tłum

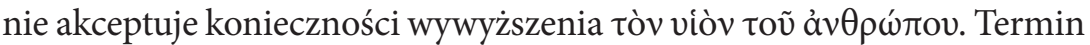
v̛ów pojawiający się czterokrotnie w Ewangelii św. Jana posiada tu inną

${ }^{71}$ Por. J. E. Bruns, The Art And Thought of John, New York 1969, s. 80. R. Reisner zestawia J 12, 28 ze sceną przemienienia ukazaną przez synoptyków i podkreśla prezentację miłości Ojca do Syna w obu tych tekstach - por. R. Reisner, Versuchung und Verklärung (Lukas 4, 1-13; 9, 28-36; 10, 17-20; 22, 39-53 und Johannes 12, 20-36), „Theologische Beiträge” 33 (2002) nr 4, s. 197-207.

72 Por. R. A. Whitacre, Joannine Polemic..., dz. cyt., s. 91.

${ }^{73}$ Por. S. Mędala, Chrystologia ewangelii św. Jana, dz. cyt., s. 313.

${ }^{74}$ Por. L. Morris, The Gospel According to John, dz. cyt., s. 599; por. L. Stachowiak, Ewangelia wedtug św. Jana, dz. cyt., s. 293. 
semantykę niż w pozostałych perykopach biblijnych - tam oznacza Boga Najwyższego, wyniesionego ponad niebiosa, tu natomiast - jak wyjaśnia sam autor natchniony w J 12, 33 - jest derywatem śmierci Jezusa. Na kartach Pisma łączony jest często z $\delta$ o $̧ a ́ \zeta \omega$, również w pieśni o Słudze Jahwe, jednak jej wpływ na J 12, 20-36 jest wciąż dyskutowany i raczej negowany ${ }^{75}$. Autor Janowy wydaje się kłaść nacisk bardziej na konieczność wywyższenia (w. 34a). Greckie $\delta \varepsilon \tilde{~ w ~ c a ł y m ~ t e k s ́ c i e ~ c z w a r t e j ~ E w a n g e l i i ~ t w o r z y ~ k l a m r e ̨: ~}$

$\mathrm{J} 3,7$ :

Nie dziw się, że powiedziałem ci: Trzeba wam się powtórnie narodzić.

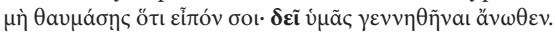

J 3, 14:

A jak Mojżesz wywyższył węża na pustyni, tak potrzeba, by wywyższono Syna Człowieczego,

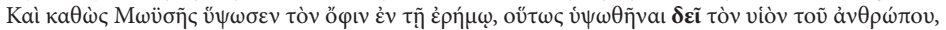

John 3, 30:

Potrzeba, by On wzrastał, a ja się umniejszał.

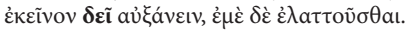

$\mathrm{J}$ 4, 20:

Ojcowie nasi oddawali cześć Bogu na tej górze, a wy mówicie, że w Jerozolimie jest miejsce, gdzie należy czcić Boga».

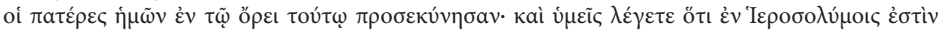

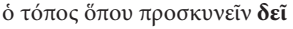

J 4, 24:

Bóg jest duchem: potrzeba więc, by czciciele Jego oddawali Mu cześć w Duchu i prawdzie».

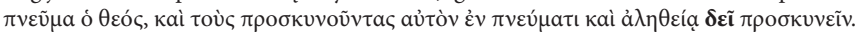

J 9,4 :

Potrzeba nam pełnić dzieła Tego, który Mnie posłał, dopóki jest dzień. Nadchodzi noc, kiedy nikt nie będzie mógł działać.

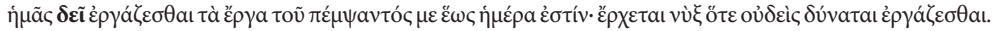
J 10, 16:

Mam także inne owce, które nie są z tej owczarni. I te muszę przyprowadzić i będą słuchać głosu mego, i nastanie jedna owczarnia, jeden pasterz.

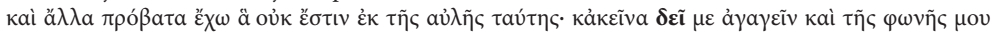

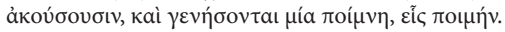

$\mathrm{J} 12,34$ :

Na to tłum Mu odpowiedział: «Myśmy się dowiedzieli z Prawa, że Mesjasz ma trwać na wieki. Jakżeż Ty możesz mówić, że potrzeba wywyższyć Syna Człowieczego? Któż to jest ten Syn Człowieczy?»

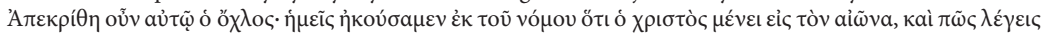
J 20, 9:

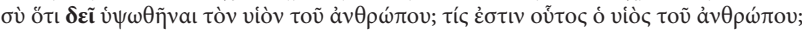

Dotąd bowiem nie rozumieli jeszcze Pisma, które mówi, że On ma powstać z martwych.

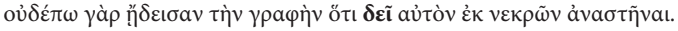

${ }^{75}$ Zob. C. A. Evans, The Voice from Heaven: A Note on John $12: 28$, „Catholic Biblical Quarterly” 43 (1981) nr 3, s. 407n. 
Wersetowi 34 z rozdz. 12 odpowiada J 3, 14 i ten paralelizm wydaje się posiadać niebagatelne znaczenie w odniesieniu do interpretacji głosu z nieba i jego percepcji w tytułowej perykopie. Ukazuje bowiem Syna Człowieczego jako Tego, który przynosi uzdrowienie (por. Lb 21, 4-9) relacji człowieka z Bogiem. Jezus zaznacza „Głos ten rozległ się nie ze względu na Mnie, ale ze względu na was” (J 12, 30). Słowa Ojca w 12, 28 są najbardziej jawnym świadectwem, jakie daje On Jezusowi w całej Janowej Ewangelii $^{76}$. Wydaje się, iż posiadają głębszy wymiar niż tylko stricte objawieniowy w znaczeniu poszerzenia wiedzy odbiorców czy też nagradzający posłuszeństwo Jezusa (w takim kluczu wielu egzegetów rozpatruje Janowe $\delta \varepsilon \tilde{\imath}^{77}$ ). Celem jest rozpoznanie Boga jako Miłości i zaangażowanie się w taką też z Nim relację. Ta bezpośrednia ingerencja Boga, jedyna w czwartej Ewangelii, nasuwa myśl o naglącej konieczności zwrócenia się ku Niemu. Przed obietnicą Jezusa: „Ja, gdy zostanę nad ziemię wywyższony, przyciągnę wszystkich do siebie" znajduje się konstatacja sądu. Greckie кpívw w literalnym odczytaniu oznacza roz-

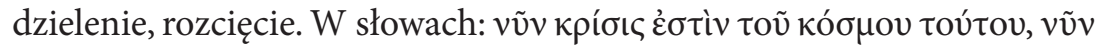

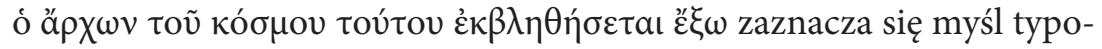
wo Janowa, niosąca ze sobą apel o opowiedzenie się po stronie Jezusa, gdyż wyrok na zło już zapadł (por. J 3, 18nn; 5, 22nn). Świat w czwartej Ewangelii posiada konotacje zdecydowanie negatywne, za postacią jego władcy kryje się szatan (por. J 14, 30), a jego strącenie to myśl, którą roz-

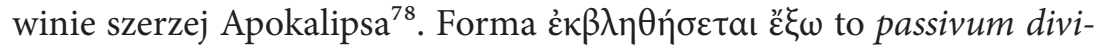
num wskazujące na ingerencję samego Stwórcy. Okolicznik czasu obecny w wyjaśnieniach Jezusa (J 12,30nn) stoi w koherencji do rozlegającego się głosu z nieba i dotyczy obecnej interwencji Boga. Warto zwrócić uwagę na fakt, iż greckie $v \tilde{v} v$ pojawia się trzykrotnie w analizowanej perykopie: w w. 27, gdzie punktuje doświadczenie lęku Jezusa, i we wspomnianym

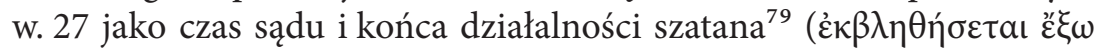

\footnotetext{
${ }^{76}$ Por. R. A. Whitacre, Johannine Polemic..., dz. cyt., s. 90.

77 Por. M. C. de Boer, Johannine Perspectives..., dz. cyt., s. 168.

${ }^{78}$ Więcej zob. J. Nowińska, Motyw wojny dobra ze złem w Apokalipsie św. Jana, dz. cyt.

${ }^{79}$ G. Goldsworthy, The Gospel in Revelation. Gospel and Apocalypse, New South Wales 1984, s. 118.
} 
dla władcy świata oznacza definitywne opuszczenie świata). Wydaje się służyć wyakcentowaniu ważności i mocy decyzyjnej teraźniejszej chwi-

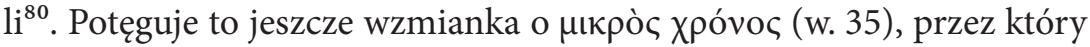
jeszcze będzie światłość. Przedmiotem, wobec którego staje człowiek, jest relacja z Ojcem ${ }^{81}$ : „Dopóki światłość macie, wierzcie w światłość, abyście byli synami światłości" - napomina Jezus w kolejnym kończącym tę scenę paralelizmie o świetle i ciemności. Ta myśl wydaje się być kontynuacją obietnicy Syna Człowieczego dotyczącej pociągnięcia ku Niemu wszystkich ludzi. I. de la Potterie ${ }^{82}$ dostrzega tu reminiscencje Jr 31, 3-14 i realizację przyciągnięcia ludu na Syjon, który niczym matka zaprasza dzieci do powrotu $\mathrm{z}$ wygnania, by je zgromadzić przy sobie. Idea wydaje się spójna $\mathrm{z}$ analizą J 12, 28 i konstatacją miłości jako celu i przedmiotu pojawienia się głosu $\mathrm{z}$ nieba, jednak podstaw $\mathrm{w}$ analogiach słownych nie posiada.

\section{Abstrakt}

Głos z nieba w J 12, 28 - jego percepcja

i wymowa teologiczna w świetle Biblii

W Biblii niebo jest zawsze wspominane w odniesieniu do Boga. Wiele razy autorzy

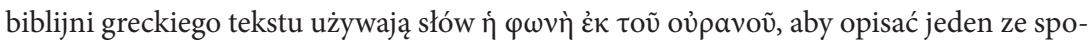
sobów działania Boga. Istnieją różne recepcje tego wyrażenia i rozmaite ludzkie reakcje - od podziwu do nieporozumienia. J 12, 28nn jest jednym z takich tekstów, więcej - jest on jakby streszczeniem różnych punktów widzenia. Poprzez analizę kontekstualną ukazuje się miłość pomiędzy Bogiem i Synem oraz zaproszenie dla każdego do uczestnictwa w tym misterium - misterium zbawienia.

${ }^{80}$ Por. C. K. Barett, The Gospel According to John, dz. cyt., s. 428.

${ }^{81}$ Por. I. de la Potterie, Męka Jezusa Chrystusa..., dz. cyt., s. 23.

82 Tamże, s. 27. 


\section{Słowa kluczowe}

Niebo, głos z nieba, miłość Boga, zbawienie

\section{Abstract}

\section{The Voice from Heaven in John 12 : 28 - its Reception and Theological Meaning in the Bible}

The heaven is always mentioned with reference to God in the Bible. Several times

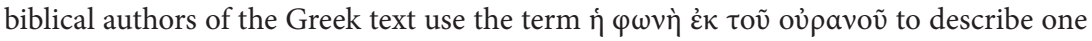
of the way God's activity. There are also various receptions of that and different human reactions - from admire to misunderstanding. John $12: 28 \mathrm{ff}$ is one of such texts - more like a summary of a few points of view. Through the contextual analyze appear the love between God and Son and invitation for everybody to participate in that mystery - mystery of salvation.

\section{Keywords}

Heaven, the voice from heaven, God's love, salvation

\section{Bibliografia}

Aune D. A., Revelation, t. 2, Dallas 1997.

Barett C. K., The Gospel According to St. John. An Introduction with Commentary and Notes on the Greek Text, t. 1, Philadelphia 1978.

Bartnicki R., Chrzest Jezusa w Jordanie w perspektywie historiozbawczej (Mk 1, 9-11; Mt 3, 13-17; Lk 3, 21-22; J 1, 29-34), [w:] R. Bogacz, W. Chrostowski, Verbum caro fatum est. Księga pamiątkowa dla Ks. Prof. Tomasza Jelonka $w 70$ rocznice urodzin, Warszawa 2007, s. 99-109.

Bednarz M., Jezus Sługq Pańskim według Nowego Testamentu, Tarnów 2001.

Blenkinsopp J., Księga Powtórzonego Prawa, [w:] B. N. Newman, A Concise Greek - English Concise Dictionary of the New Testament, Stuttgart 1993. 
Boer M. C. de, Johannine Perspectives on the Heath of Jesus, Kampen 1996.

Browing W. R. E., Słownik biblijny, Warszawa 2009.

Brown R. E., The Gospel According to John, t. 1, New York 1966.

Bruns J. E., The Art And Thought of John, New York 1969.

Brzegowy T., Pięcioksiąg Mojżesza, Tarnów 2002, s. 220.

Burge G., Revelation and Discipleship in St. John's Gospel, [w:] Challenging Perspectives on the Gospel of John, ed. by J. Lierman, Tübingen 2006, s. 235-251.

Cadman W. H., The Open Heaven. The Revelation of God in the Johannine Sayings of Jesus, New York 1969.

Campbell A. F., Flanagan J. W., Pierwsza i Druga Księga Samuela, [w:] Katolicki komentarz biblijny, red. nauk. wyd. oryg. R. E. Brown, J. A. Fitzmyer, R. E. Murphy, red. nauk. wyd. pol. W. Chrostowski, Warszawa 2001.

Collins A. Y., Niebo, [w:] Encyklopedia biblijna, red. P. A. Achtemeier, Warszawa 1999.

Dodd C. H., Historical Tradition in the Fourth Gospel, Cambridge 1963.

Evans C. A., The Voice from Heaven: A Note on John 12:28, „Catholic Biblical Quarterly" 43 (1981) nr 3.

Fouilloux D. i in., Kultura biblijna. Słownik, tł. M. Żurowska, red. nauk. W. Chrostowski, Warszawa 1997.

Friberg T., Analytical Lexicon to the Greek New Testament, Grand Rapids, MI 1994.

Goldsworthy G., The Gospel in Revelation. Gospel and Apocalypse, New South Wales 1984.

Gramatyka opisowa języka polskiego z ćwiczeniami, pod red. W. Doroszewskiego i B. Wieczorkiewicza, t. 2, Warszawa 1961.

Haręzga S., Jezus i Jego uczniowie. Model chrześcijańskiej formacji w Ewangelii według św. Marka, Lublin 2006.

Harris R. L., Archer L., Waltke B. K., The Theological Wordbook of the Old Testament, Chicago, Ill. 1980.

Lightfoot P. H., St. John's. A Commentary, London 1966.

Louw J. P., Nida E. A., Greek-English Lexicon of the New Testament Based on Semantic Domains, New York 1988.

Malina A., Pedagogia i tajemnica głosu Boga (Mk 1, 11; 9, 7), „Verbum Vitae” 7 (2005), s. 93-118.

Mędala S., Chrystologia ewangelii św. Jana, Kraków 1993.

Moloney F. J., The Gospel of John, t. 4, Collegeville 1998.

Morris L., The Gospel According to John. The English Text with Introduction, Exposition and Notes, Grand Rapids, Mich. 1971. 
Newman B. N., A Concise Greek-English dictionary of the New Testament, Stuttgart 1993.

Neyrey J. H., The Gospel of John, Cambridge 2007.

Nowińska J., Ap 12 jako teologia historii, „Ruch Biblijny i Liturgiczny” 62 (2009) nr 4, s. 269-283.

Nowińska J., Motyw wojny dobra ze złem w Apokalipsie św. Jana, Warszawa 2006.

Paciorek A., Ewangelia według świętego Mateusza. Wstęp, przekład z oryginału, komentarz, rozdziały 14-28, Częstochowa 2008.

Parchem M., Księga Daniela. Wstęp, przekład z oryginatu, komentarz, Częstochowa 2008.

Popowski R., Wielki słownik grecko-polski Nowego Testamentu, Warszawa 1997.

Potterie I. de la, Męka Jezusa Chrystusa według Ewangelii Jana, Kraków 2006.

Rad G. von, Holy War in Ancient Israel, Michigan 1991.

Reisner R., Versuchung und Verklärung (Lukas 4, 1-13; 9, 28-36; 10, 17-20; 22, 39-

53 und Johannes 12, 20-36), „Theologische Beiträge” 33 (2002) nr 4, s. 197-207.

Sobol E., Stownik wyrazów obcych, Warszawa 2000.

Stachowiak L., Ewangelia według św. Jana, Poznań 1975.

Szymik S., Imiona 'El oraz 'Elohîm jako określenia Boga w Biblii Hebrajskiej, [w:] Mów, Panie, bo sługa Twój stucha. Księga pamiątkowa dla Księdza Profesora Ryszarda Rubinkiewicza SDB w 60. rocznicę urodzin, zebr. i oprac. W. Chrostowski, Warszawa 1999, s. 206-218.

św. Tomasz z Akwinu, Komentarz do ewangelii Jana, Kęty 2002.

Tronina A., Bóg przybywa z Synaju. Staroizraelskie formuly teofanijne a początki religii Izraela, Lublin 1989.

Uglorz M., Jahwe - Bóg Izraela. Zarys starotestamentowej teologii Boga, Warszawa 2002.

Whitacre R. A., Joannine Polemic. The Role of Tradition and Theology, Chico 1982.

Whitaker's Revised BDB Hebrew-English Lexicon, [w:] BibleWorks 6.

Witczyk H., „Pokorny wołał i Pan go wystuchał” (Ps 34,7a). Model komunikacji diafonicznej w Psalmach, Lublin 1997.

Witczyk H., Teofania w Psalmach, Kraków 1985. 
